\title{
SS-051 相互行為・相互交渉場面における身体化された音楽性
}

\author{
企画代表者, 司会者: 外山 紀子 (早稲田大学) \\ 企画者: 根ケ山光一 (早稲田大学) \\ 話題提供者 : 古山 宣洋 (早稲田大学) \\ 話題提供者: 細馬 宏通\# (滋賀県立大学) \\ 話題提供者: 石島このみ (早稲田大学) \\ 指定討論者 : 志村 洋子\# (同志社大学)
}

二者以上の相互交渉・相互行為場面では, 身体運動のテンポやタイミング, 動きのパターンの一致や 重なりが, 円滑な, あるいは相互的なインタラクションの基盤となる。動きのずれやはぐらかしは, 時 として思わ奴展開をもたらし，相互交涉のスパイスになることもある。本シンポジウムでは，身体運動 や発声, 発話のテンポ, リズム, メロディー, 起承転結といった構成を音楽性 (musicality) と呼び, ヒ トのコミュニケーションにおけるその原初的役割を考察する。

3 名の話題提供者には, 音楽性の基本骨格としてのテンポ・同期 (古山氏), 会話の中の音楽的要素 (細馬氏)，親子の身体遊びに組み込まれた物語性（石島氏）についてそれぞれお話しいただく。

第2 日 9 月23日(水) $13: 10 \sim 15: 10$

第 8 会場 /レセプションホール第 2 室（西）

\section{SS-052 再登校支援における家庭訪問支援技法の開発と可能性}

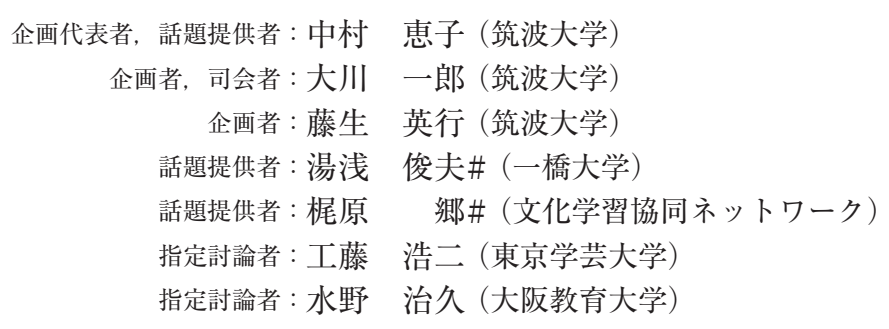

再登校支援には家庭訪問が重要な役割を担う。しかし, 家庭訪問に焦点化した研究は少なく, 欧米の 教育制度ではホームスクーリングが選択できるため訪問教育として位置づけられ，再登校支援技法とと らえられていない。

ホームスクーリングが認められていない日本の学校現場では長期不登校生徒への支援は困難を極めて いる。教師には登校しない生徒を対象に個別支援を行う十分な余裕がなく，それを補う支援システムが 整備されているといえないからである。家庭訪問はじめ個別支援を継続的に行うためには, SCや SSW など関係諸機関の子ども支援職者との連携が必要である。

本シンポジウムでは, 家庭訪問を主業務として不登校生徒の自立支援を行う A 福祉事務所での子ども 支援の実践を紹介する。併せて学校臨床での長期不登校事例を報告し, 現状における不登校に対する個 別支援の限界と多職種連携による支援の可能性ならびに家庭訪問支援の在り方について討議する。 